\title{
Alveolar echinococcosis in a highly endemic area of northern Slovakia between 2000 and 2013
}

D Antolová (antolova@saske.sk)1, M Miterpáková1, J Radoňák2, D Hudačková3, M Szilágyiová4, M Žáček5

1. Institute of Parasitology, Slovak Academy of Sciences, Košice, Slovakia

2. First Department of Surgery, University Hospital Košice, Košice, Slovakia

3. Childrens' Faculty Hospital Košice, Department of Infectious Diseases, Košice, Slovakia

4. Clinic of Infectious Diseases and Travel Medicine, University Hospital Martin, Martin,

5. Department of Surgery, University Hospital Žilina, Žilina, Slovakia

Antolová D, Miterpáková M, Radoňák J, Hudačková D, Szilágyiová M, Žáček M. Alveolar echinococcosis in a highly endemic area of northern Slovakia between 2000 and 2013. Euro Surveill. 2014;19(34):pii=20882. Available online: http://www.eurosurveillance.org/ViewArticle.aspx?Articleld=20882

Long-term surveillance of Echinococcus multilocularis occurrence in red foxes in Slovakia revealed the existence of highly endemic areas, with an overall prevalence rate of $41.6 \%$ in the northern part of the country. Between 2000 and 2013, 26 human cases of alveolar echinococcosis were detected and only three of them were not in endemic localities in northern Slovakia. Remarkable is the occurrence of the disease in eight people younger than 35 years, including three patients aged eight, 14 and 19 years. Occurrence of $E$. multilocularis in red foxes throughout the country and high incidence of alveolar echinococcosis in young people indicate high infectious pressure in the environment of northern Slovakia. It can be assumed that the real incidence of alveolar echinococcosis is significantly higher than recorded by official data due to the lack of existing registration and reporting system. For effective management of prevention and control strategies for this disease improvement of the national surveillance system and engagement of specialists outside the medical community are necessary. Our study presents a comprehensive picture of the epidemiological situation of $E$. multilocularis in northern Slovakia. In addition, we report the first list of confirmed human cases of this serious parasitosis in Slovakia.

\section{Introduction}

Echinococcus multilocularis, causative agent of alveolar echinococcosis in humans, has become the target of intensive research at the beginning of the $1980 \mathrm{~s}$ [1]. In the past decades, the known range of the parasite in Europe has expanded. The formerly known geographical range of the parasite included regions of (by date of detection) Austria, Switzerland, France, Germany, Liechtenstein, Luxembourg, Denmark, the Baltic states, Belgium, the Netherlands, northern Italy, Poland, the Czech Republic, Slovakia, northern Hungary and Slovenia [2,3]. Recently, the occurrence of E. multilocularis was for the first time confirmed also in Sweden [4,5], and in southern Denmark, a new highendemic focus was detected [6]. The importance of the issue is highlighted by a recent regulation issued by the European Commission in 2011 [7]. The aim of the measures outlined in the regulation is to minimise the risk of introducing the parasite into territories where it has not yet been detected, namely Finland, the United Kingdom, Ireland and Malta [7].

In Slovakia, E. multilocularis was detected for the first time in red foxes in 1999 [8] and intensive epidemiological studies have been carried out since. During the surveillance of E. multilocularis between 2000 and 2010, more than 4,700 red foxes (Vulpes vulpes) from all regions of the country have been examined. The total average prevalence of the parasite was 30.3\% and the existence of highly endemic areas in northern regions of Slovakia was revealed [9].

The survey presents a comprehensive picture of the epidemiological situation of $E$. multilocularis in highly endemic regions of northern Slovakia from its first detection in 1999 until 2012 and includes results from the territory of the High Tatras National Park. Moreover, we report here the first list of confirmed human cases of this serious parasitic disease.

\section{Methods}

Collection and examination of red foxes

Monitoring of $E$. multilocularis in red foxes living in northern Slovakia (Žilina and Prešov Region including the High Tatras National Park) was conducted in the years 2000 to 2005,2007 , and 2010 to 2012. Red foxes were collected in the framework of the control of the effectiveness of anti-rabies vaccination carried out twice a year, in spring/summer and autumn/winter campaigns. The number of samples and the time schedule of campaigns were set by the State Veterinary and Food Administration of the Slovak Republic. From each of 79 Slovak districts, a representative sample of at least six foxes per campaign was shot. Animals originating from the protected area of the High Tatras 
National Park were found dead, road-killed or legally hunted by workers of the Tatra National Park Research Station. Small intestines of the animals were deepfrozen at $-80^{\circ} \mathrm{C}$ prior to necropsy and parasitological examination. Sedimentation and counting method [10] with modification of using $0.09 \mathrm{~mm}$ mesh analytic sieves for washed fraction filtration [9] was applied for E. multilocularis detection.

\section{Climatic data collection}

Influence of climatic factors (mean annual air temperature and mean annual precipitation) on the prevalence rate of $E$. multilocularis in red foxes in individual years was assessed. The data were obtained from datasets of Statistical Office of the Slovak Republic [11]. Data measured at three weather observatories in northern Slovakia (Oravská Lesná - Žilina Region, Poprad and Stropkov - Prešov Region) were used for this purpose.

\section{Collection and examination of dog samples for Echinococcus multilocularis}

To determine the role of dogs in the spread of the disease in highly endemic areas, 138 animals originating from the northern areas of Slovakia (Prešov and Žilina Region) were collected between 2002 and 2005. Faecal samples came from stray and owned dogs that were not dewormed regularly with the last deworming treatment at least four months before examination. In order to reduce the risk of infection, all samples were deep-frozen at $-80{ }^{\circ} \mathrm{C}$ for at least seven days prior to examination.

Data concerning the age, sex, locality and usage of dogs were gathered with the help of a questionnaire. Other questions were related to how often the dogs could move freely in rural areas, were fed with raw viscera or caught rodents. Animals aged up to 10 months were classified as young, older animals were identified as adults.

Nested PCR was used to detect the presence of E. multilocularis DNA in faecal samples [12].

\section{Statistical analyses}

The prevalence of $E$. multilocularis in the examined dog and red fox population was calculated. The seroprevalence values were given with $95 \%$ confidence intervals $(\mathrm{Cl})$, and odds ratios (OR) were calculated to estimate the association between variables included in the study (age, sex, utilisation, etc.) and the risk of echinococcosis. All statistical analyses were conducted using STATISTICA 6 Base (StatSoft, Inc, 2001).

\section{Sampling and diagnostics of alveolar}

\section{echinococcosis in humans}

Human samples and data about the patients were collected in cooperation with medical doctors and hospitals, especially with infectious disease and surgical clinics from different regions in Slovakia. Sera from patients suspected for echinococcosis, e.g. patients with clinical symptoms of echinococcosis or patients with cystic lesions found during imaging examination (ultrasonography (USG), radiography, computed tomography (CT)) were sent to the Institute of Parasitology SAS (IP SAS) for serological examination. At the beginning, IP SAS was the only laboratory where antibodies to Echinococcus could be examined. After a few years, private laboratories started with serological diagnostics and it could not be estimated how many samples were sent elsewhere. Currently, IP SAS is the only laboratory performing Western blot and PCR tests. Specific antibodies to E. multilocularis were detected by modified ELISA $[13,14]$ or commercial ELISA test kits (Novalisa Echinococcus IgG, NovaTec Immunodiagnostica, Germany), and positive sera of patients who had not undergone surgery, i.e. for whom PCR samples or histology were not available, were examined also by Western blot (Echinococcus WB IgG, LDBIO Diagnostics, France). Imaging techniques (USG, $\mathrm{CT}$, magnetic resonance imaging (MRI)) were performed to detect the presence of parasitic lesions in the liver and other organs, and material obtained during surgery was submitted to histological and/or PCR examination [15]. Some clinical cases were detected accidentally, during surgical intervention for another disease.

The diagnosis was confirmed if at least two of following four parameters were verified [16]: (i) typical organ lesions detected by imaging techniques, (ii) presence of antibodies to Echinococcus multilocularis (ELISA, Western Blot), (iii) histological findings compatible with $E$. multilocularis metacestode, or (iv) detection of E. multilocularis DNA by PCR methods.

\section{Results}

Surveillance of Echinococcus multilocularis in red foxes in northern Slovakia during 2000 to 2012

Since 2000 , a total of 1,875 red foxes originating from the northern Slovak regions have been examined for $E$. multilocularis presence. The tapeworm was detected in the small intestines of 779 foxes ( $41.6 \%$ ), with a mean prevalence rate in the Žilina and Prešov Region of $47.7 \%$ and $38.5 \%$, respectively (Figure 1 ).

The annual prevalence varied between $26.0 \%$ in 2007 and more than $50.0 \%$ in 2001, 2005 and 2010. The mean worm burden reached 2.352 tapeworms per infected fox (Table 1).

Considerable correlation was observed between prevalence of $E$. multilocularis in red foxes and the mean annual air temperature, as well as between prevalence and mean annual precipitation. The prevalence reached the highest values (50.8-58.4\%) during the cold and wet years of 2001, 2005 and 2010 (Figure 2). In contrast, prevalence significantly decreased (to $30.2 \%$, $26.0 \%$ and $27.3 \%$, respectively) in the much drier years 2003, 2007 and 2012 (Table 1) [17]. 
Occurrence of alveolar echinococcosis in humans $(\mathrm{n}=26)$ and mean prevalence of Echinococcus multilocularis in red foxes in the Žilina and Prešov Regions, Slovakia 2000-2012

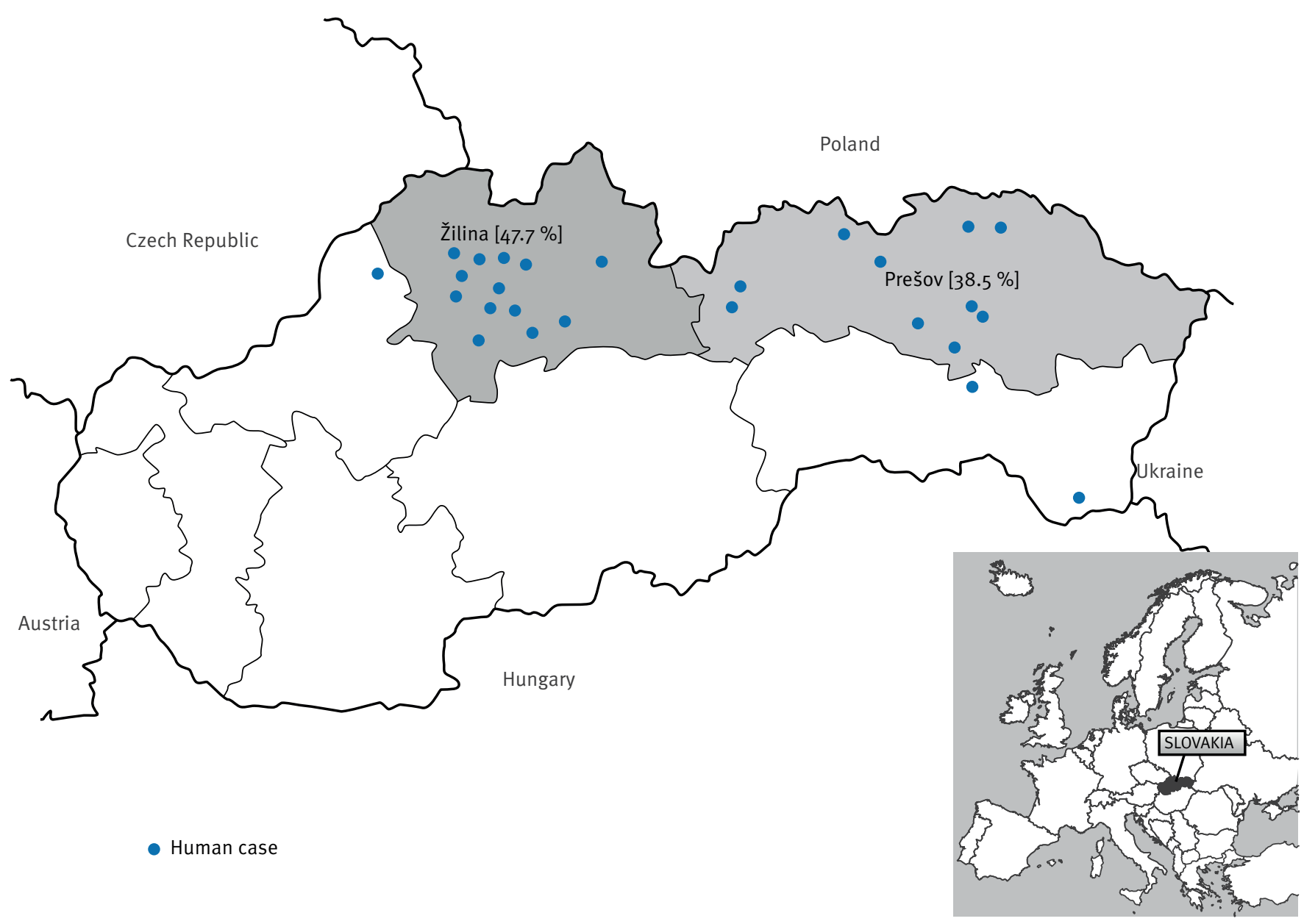

Locations of human cases are indicated as dots. Echinococcus multilocularis prevalence in foxes is indicated in square brackets. AT: Austria; CZ: Czech Republic; HU: Hungary; PL: Poland; UA: Ukraine.

\section{Echinococcus multilocularis in dogs}

Of 138 dog faeces examined, E. multilocularis DNA was confirmed in four (2.9\%) samples. The majority, 119 samples, came from the Prešov Region with three infected animals (2.5\%). Among the 19 animals from the Žilina Region, one sample (5.2\%) was found to be positive.

The positive animals were used as guard and shepherd dogs, but neither usage of the dogs nor their age or sex influenced the occurrence of parasites significantly (p>0.05).
Data about free movement in rural areas, feeding and catching rodents were known for 82 cases. Positivity for $E$. multilocularis was closely correlated with the possibility to catch the rodents $(p=0.04 ; O R=9.4 ; 95 \%$ $\mathrm{Cl}$ : 0.9-95.9) and uncontrolled movement in rural areas $(p=0.02 ; O R=14.5 ; 95 \% \mathrm{Cl}: 1.4-145.5)$. Feeding with raw viscera was not identified as a risk factor for infection (Table 2).

\section{Human cases of alveolar echinococcosis in} Slovakia

The first case of alveolar echinococcosis in Slovakia was confirmed in 2000 in a woman in her 60 s from a village in the Žilina Region (north-western Slovakia). 


\begin{tabular}{|c|c|c|c|c|c|c|}
\hline Year & $\begin{array}{l}\text { Mean annual air } \\
\text { temperature }{ }^{\circ}\left({ }^{\circ} \mathrm{C}\right)\end{array}$ & $\begin{array}{l}\text { Mean annual } \\
\text { precipitations } \\
(\mathrm{mm})\end{array}$ & $\begin{array}{c}\text { Number of foxes } \\
\text { examined }\end{array}$ & $\begin{array}{l}\text { Number of foxes } \\
\text { infected }\end{array}$ & $\begin{array}{l}\text { Prevalence \% } \\
\text { (range) }\end{array}$ & $\begin{array}{l}\text { Mean worm } \\
\text { burden } \\
\text { Number per fox } \\
\text { (range) }\end{array}$ \\
\hline 2000 & $7 \cdot 7$ & 902.1 & 175 & 48 & $\begin{array}{c}27.4 \\
(19.0-36.3)\end{array}$ & NA \\
\hline 2001 & 6.7 & 962.8 & 185 & 108 & $\begin{array}{c}58.4 \\
(48.8-67.5) \\
\end{array}$ & $\begin{array}{c}1,426 \\
(1-25.000)\end{array}$ \\
\hline 2002 & $7 \cdot 4$ & 865.7 & 175 & 90 & $\begin{array}{c}51.4 \\
(42.2-60.6) \\
\end{array}$ & $\begin{array}{c}1,930 \\
(2-40.000) \\
\end{array}$ \\
\hline 2003 & 6.8 & 629.6 & 301 & 91 & $\begin{array}{c}30.2 \\
(25.6-35 \cdot 3) \\
\end{array}$ & $\begin{array}{c}495 \\
(1-10.500) \\
\end{array}$ \\
\hline 2004 & 6.5 & 895.7 & 247 & 108 & $\begin{array}{c}43.7 \\
(43.7-39.0) \\
\end{array}$ & $\begin{array}{c}1,497 \\
(1-16.000) \\
\end{array}$ \\
\hline 2005 & 6.0 & 949.2 & 333 & 169 & $\begin{array}{c}50.8 \\
(45.2-56.3) \\
\end{array}$ & $\begin{array}{c}5,013 \\
(2-59.900) \\
\end{array}$ \\
\hline 2007 & 6.8 & 701.0 & 158 & 41 & $\begin{array}{c}25.9 \\
(18.9-34.1) \\
\end{array}$ & $\begin{array}{c}11,027 \\
(5-245.000) \\
\end{array}$ \\
\hline 2010 & 6.5 & $1,155.2$ & 122 & 68 & $\begin{array}{c}55.7 \\
(48.1-63.1) \\
\end{array}$ & $\begin{array}{c}1,093 \\
(1-19.900)\end{array}$ \\
\hline 2011 & NA & NA & 58 & 23 & $\begin{array}{c}39.7 \\
(29.6-50.3) \\
\end{array}$ & $\begin{array}{c}1,096 \\
(2-37.920)\end{array}$ \\
\hline 2012 & NA & NA & 121 & 33 & $\begin{array}{c}27.3 \\
(20.1-35.0) \\
\end{array}$ & $\begin{array}{c}3,232 \\
(3-33.120)\end{array}$ \\
\hline Total & - & - & 1,875 & 779 & 41.6 & $\begin{array}{c}2,352 \\
(1-245.000)\end{array}$ \\
\hline
\end{tabular}

NA: data become available in full-scale form with a delay of two years.

a Measured at three weather observatories in northern Slovakia (Oravská Lesná, Poprad, Stropkov).

Although the first clinical symptoms of the disease had appeared already in 1994, the lack of knowledge about the presence of $E$. multilocularis on the territory of Slovakia probably resulted in misdiagnosis. In the patient's anamnesis, a history of keeping a dog and collecting forest fruits were of epidemiological importance [18].

In the same year, a second case of autochthonous alveolar echinococcosis was detected. The patient was a woman in her 70s, from a village in mountain area of north-western Slovakia (Žilina Region), who spent a lot of time at her mountain cottage where she grew vegetables. Except weight loss, the patient had no clinical signs, and the disease was noticed only after observing the high erythrocyte sedimentation rate during a routine medical examination. Subsequent USG and CT examination of the abdomen revealed an irregularly shaped focus $12 \times 11 \times 10 \mathrm{~cm}$ in the right liver lobe. Serological (ELISA, Western blot) and histological examinations confirmed the diagnosis of alveolar echinococcosis [19].

Three years later, in 2004, two further cases were verified. The patients were men from the Prešov and Žilina Region. Since then, new cases of alveolar echinococcosis have been detected every year (Figure 3). The incidence of the disease has followed an increasing trend. As of April 2013, the total number of alveolar echinococcosis in Slovakia has reached 26 cases (Figure 1). Only three of these patients did not come from the highly endemic Prešov or Žilina Regions. One woman came from the Trenčín Region, situated in the west of Slovakia and neighbouring the Žilina Region, and two persons were from the Košice Region neighbouring the Prešov Region (Figure 1). The mean age of the patients was $52.3 \pm 20.7$ years, ranging between eight and 78 years. Only negligible differences were recorded between the positivity of women (14 cases) and men (12 cases).

In addition to the 26 confirmed cases of alveolar echinococcosis, at least 10 other cases were detected between 2007 and 2012 in whom the aetiological agent of echinococcosis was not determined. In these patients, the diagnosis of echinococcosis was made after serological and USG examination. However, material for histological or PCR examination that could facilitate the confirmation of diagnosis could not be obtained because of the good response to anthelmintic treatment that made surgical intervention unnecessary, or because the patients neglected to appear for their control examination.

Three of the 26 confirmed patients were younger than 20 , one of them even younger than 10 years (Table 3 ). In 2006, alveolar echinococcosis was diagnosed in a teenager from the Prešov Region, living in close vicinity of 


\section{FIGURE 2}

Positive correlation between Echinococcus multilocularis prevalence in red foxes and mean annual precipitation ${ }^{\mathrm{a}}$, northern Slovakia, 2000-2010

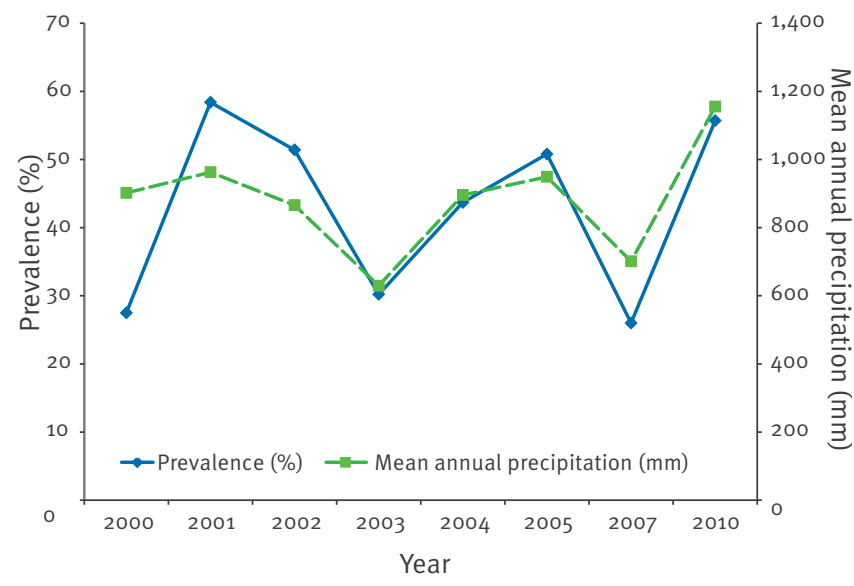

${ }^{a}$ Measured at three weather observatories (Oravská Lesná, Poprad, Stropkov).

a forest. The patient suffered from headache, fatigue, cough, fever and abdominal enlargement. USG examination confirmed tumour-like infiltrations in the right and left liver lobes and the diagnosis of echinococcosis was confirmed by ELISA, Western blot and histological examination [20]. In 2012, two more cases of alveolar echinococcosis in young patients were detected. One was a teenager from the Žilina Region with multiple cysts in the liver and four cysts in the lungs, found by USG examination; the diagnosis was confirmed by PCR after the resection of suspicious parasitic material from the liver. The other case was younger and came from the Prešov Region, with a primary infection site in the right femur; no other lesions were confirmed using USG and PET-CT examinations. This case was living near the forest at the end of a village, in close vicinity to an area often visited by red foxes. The family also owned a dog. Although the first symptoms, pain in the right leg and knee, were not indicative of alveolar echinococcosis, serological examination confirmed the presence of antibodies to Echinococcus spp. Following histological investigation of material obtained during surgical intervention, Western blot of the serum sample and PCR analyses of DNA from the cyst secretion confirmed the diagnosis of alveolar echinococcosis.

\section{Discussion and conclusion}

Our monitoring confirms the presence of highly endemic areas of $E$. multilocularis in the northern part of Slovakia, with a mean prevalence rate of almost $42.0 \%$ in its main definitive hosts, red foxes. This 12-year examination of red foxes has unfolded great fluctuation of $E$. multilocularis prevalence between years, probably depending on climatic conditions. Prevalence rates were highest during the cold and wet years of 2001, 2005 and 2010. In those years precipitation totals were considerably above normal. In contrast, prevalence significantly decreased in the warmer years of 2003, 2007 and 2012, which were the first, third and fourth warmest years since 1871 in Slovakia [17].

Given that $E$. multilocularis is considered a parasite adapted to cold climate, environmental conditions of northern Slovakia are very suitable for the spread of echinococcosis. The area is characterised by mountain climate with average annual temperatures between -3 and $+4{ }^{\circ} \mathrm{C}$. Annually, rainfall varies between 800 and $2000 \mathrm{~mm}$. Main recreational areas of Slovakia are situated in northern Slovakia, which is of relevance from a public health point of view. Žilina Region is dominated by national parks, and $51.0 \%$ of its territory is under some form of protection, accounting for $30.0 \%$ of Slovakia's total protected area. In the territory of the Prešov Region are situated the only truly alpine mountains in Eastern Europe, the Tatra National Park [11]. In the past decades, touristic activities have increased, not only in the National Parks but all over the country. The estimated number of tourists visiting Tatra National Park exceeds 3,500,000 per year [21]. In addition, the risk of human infection is also influenced by high population density and urbanisation of red foxes (and other free-living carnivores) in these areas.

Due to close contact with humans and contamination of soil around houses and in gardens, dogs present a considerable risk factor in the spread of echinococcosis to humans. Stehr-Green et al. and Kern et al. identified ownership of a dog as associated with acquisition

\section{TABLE 2}

Impact of usage, feeding and catching rodents on the occurrence of Echinococcus multilocularis in dogs, 2000-2005

\begin{tabular}{|l|c|c|}
\hline Variable & $\begin{array}{c}\text { Positive/examined } \\
(\%)\end{array}$ & $95 \% \mathrm{Cl}$ \\
\hline Usage & $0 / 47(0.0)$ & -2.8 to 13.5 \\
\hline Hunting dogs & $2 / 35(5.7)$ & $1.1-17.4$ \\
\hline Guard dogs & $2 / 26(7.7)$ & $1.4-24.6$ \\
\hline Shepherd dogs & $0 / 11(0.0)$ & $0.0-26.4$ \\
\hline Pet dogs & $0 / 19(0.0)$ & $0.0-17.6$ \\
\hline Unknown & $3 / 26(11.5)$ & $3.2-30.2$ \\
\hline Fed with raw viscera & $1 / 41(2.4)$ & -0.5 to 14.5 \\
\hline Yes & $0 / 15(0.0)$ & $0.0-22.2$ \\
\hline No & $1 / 11(0.1)$ & $0.5-40.4$ \\
\hline I don't know & $3 / 17(17.6)$ & $4.9-41.7$ \\
\hline Catching rodents & $1 / 54(1.9)$ & $0.2-7.4$ \\
\hline Yes & $1 / 14$ & \\
\hline No & & \\
\hline I don't know & & \\
\hline
\end{tabular}

$\mathrm{Cl}$ : confidence interval. 
TABLE 3

Age of first diagnosis of alveolar echinococcosis, Slovakia, 2000-2012 $(n=26)$

\begin{tabular}{|l|c|c|}
\hline Age category & Number of cases & $\begin{array}{c}\text { Incidence/100,000 } \\
\text { inhabitants }\end{array}$ \\
\hline <10 years & 1 & 0.18 \\
\hline $10-19$ years & 2 & 0.31 \\
\hline $20-29$ years & 1 & 0.12 \\
\hline $30-39$ years & 4 & 0.45 \\
\hline $40-49$ years & 0 & 0.00 \\
\hline $50-59$ years & 5 & 0.65 \\
\hline $60-69$ years & 7 & 1.40 \\
\hline$>70$ years & 6 & 1.33 \\
\hline
\end{tabular}

according to number of inhabitants in 2010 [36].

of the disease $[22,23]$. Some of the dogs $(2.9 \%)$ in our study were infected with E. multilocularis and could be a source of human infection. Catching rodents and unattended movement in rural areas were correlated with infection of dogs. Of course, a larger number of samples and further epidemiological analyses would be more valuable, but due to limited staff we did not continue the examination of dogs after 2005. Budke et al. and Ziadinov et al. also recognised a higher probability of infection in dogs that hunt rodents, in hunting dogs and in non-restrained dogs [24,25]. Although E. multilocularis is not common in dogs in Slovakia, contact with animals with risk behaviour increases the probability of infection, especially in highly endemic regions of the country.

The list of diagnosed human cases of alveolar echinococcosis confirms northern Slovakia as a risk area. Of 26 infected humans, only three lived outside the Žilina or Prešov Region. However, the prevalence of $E$. multilocularis in red foxes also reaches $18.4 \%$ in the Košice Region and as much as $40.3 \%$ in the Trenčín Region [9]. Thus, the risk of infection in areas in regions other than Žilina and Prešov is not negligible and a rise in the number of new cases is possible in the future. Moreover, as northern Slovakia is a popular tourist destination, we cannot exclude the infection of the three patients in highly endemic localities.

Humans are considered to be unsuitable hosts for E. multilocularis [26]. Therefore, it is assumed that repeated or long-term exposure to contaminated environment is needed to establish the infection [27]. In addition, the long incubation period (five to 15 years) contributes to the fact that alveolar echinococcosis is mainly diagnosed in older patients. The mean age of patients with alveolar echinococcosis in Slovakia was 52.3 years, but remarkable is the occurrence of alveolar echinococcosis in three persons younger than 20 years. Two of them came from the Prešov Region and one lived in the Žilina Region. All three patients had severe organ damage indicating their exposure to E. multilocularis in early childhood. The mean age of patients reported to the European Echinococcosis Registry between 1982 and 2000 was 52.5 years, but only $2.1 \%$ of 559 persons were younger than 20 years [27]. Similarly, $2.1 \%$ and $5.2 \%$ of patients with affirmed alveolar echinococcosis in the highly endemic Ningxia Hui Region of China were younger than 20 years and 30 years, respectively [28]. On the other hand, relatively high occurrence of the disease in children was recorded in Poland, a country neighbouring Slovakia, where among 121 human cases, four (3.3\%) were between the ages of six and 11 years, and the mean age of patients with alveolar echinococcosis was only 47.6 years [29]. In Poland, E. multilocularis in red foxes was detected for the first time in 1995 [30] and one of the endemic localities, the Subcarpathian Province, is situated in the south of the country and borders with the highly endemic Žilina and Prešov Regions of Slovakia. Although the reason for increased incidence of alveolar echinococcosis in young people recorded in this study is unknown, we speculated that the environment of northern Slovakia is highly contaminated with infective stages of E. multilocularis.

The short interval between the first detection of E. multilocularis in foxes and the first human case (with severe organ damage) suggests that the parasite was present in Slovakia before 1999. Since then, increased awareness of public health authorities and physicians the possibility of serological examination of serum samples and new diagnostic methods, together with a constant high prevalence of the parasite in red foxes and increased density of the fox population, has contributed to an increase in the number of human cases detected, especially since 2010.

We can assume that the real number of human alveolar echinococcosis may be several time higher than that shown by official data. A similar situation was recorded

\section{FIGURE 3}

Confirmed human cases of alveolar echinococcosis, Slovakia, 2000-2013 (n=26)

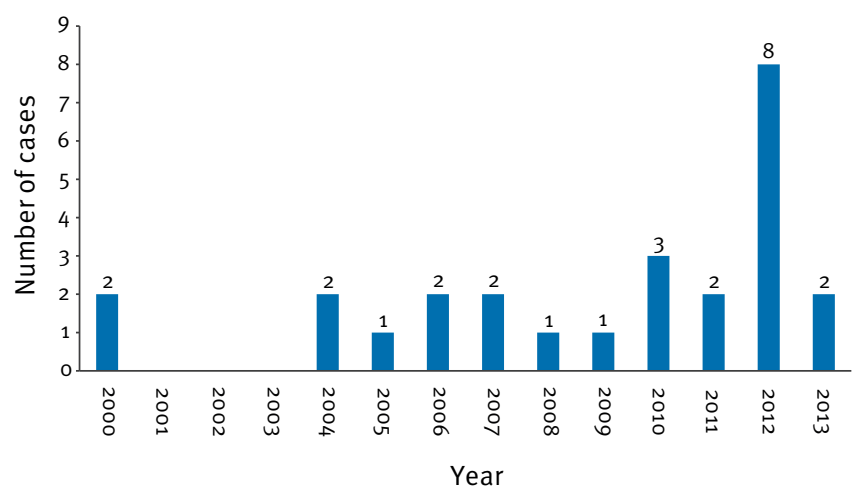


also in other countries; Jorgensen et al., for example, estimate that the incidence of the infection in Germany is three times higher than national surveillance data [31]. In Slovakia, confirmed cases of echinococcosis are reportable to the Regional Authorities of Public Health (RAPH) operated under Ministry of Health, and thereafter, the data are sent to the Epidemiological Information System (EPIS) or reported directly to the EPIS. Such a reporting system has some limitations since reports to EPIS come only from physicians and pathologists registered in the system. On the other hand, reports to the RAPH come from microbiological or parasitological laboratories. Due to the fact that each party relies on the other to report diagnosed cases, many cases can be neglected and the incidence can thus be seriously underestimated. Moreover, in many cases the diagnosis is established only as echinococcosis, and the aetiological agent of the disease, E. multilocularis or $E$. granulosus, is not determined. Similarly, the European Food Safety Authority (EFSA) supposes that current data about the occurrence of human echinococcosis in Member States of the European Union do not provide an accurate picture of the epidemiological situation. In 2010 , approximately $22 \%$ of human cases remained undetermined [32]. Distinction between infections with E. granulosus and E. multilocularis would be beneficial because the two diseases require different management of prevention and treatment [32].

Despite the fact that alveolar echinococcosis was discovered in Slovakia already 13 years ago and despite (or maybe because of) the popularisation of this medical problem, public knowledge on its epidemiology is still greatly misleading. In Slovakia, as in other European countries, biased information about eating berries and mushrooms as the most important infection risk factor is often promoted in media, while little consideration is given to ownership of dogs and contact with wild carnivores. Nevertheless, several case-control studies aimed at investigating the epidemiology of alveolar echinococcosis have affirmed ownership of dogs and contact with carnivores as the most important risk factors $[22,23,33]$. Therefore, regular deworming treatment of dogs could be an effective preventive measure. In contrast, two studies from 2004 and 2005 did not find an association of alveolar echinococcosis with picking and eating berries and mushrooms from fields and forests $[23,34]$.

The above facts draw attention to the need to revise the existing reporting system, improve the national surveillance system and engage specialists outside the medical community (public health professionals, parasitologists, veterinarians, zoologists and ecologists) for effective management of prevention and control strategies. Knowledge on how to minimise the risk of E. multilocularis transmission is not yet established in new endemic areas. Eradication of the parasite from the environment by means of long-term baiting campaigns in the fox population appears to be an effective tool, but has never been completely successful $[35,36]$.
The baiting programmes depend strongly on several factors, mainly on available financial resources. Therefore the prevention of human alveolar echinococcosis should be based on integrated control measures such as increasing public awareness of hygienic measures, regular anthelmintic treatment of domestic carnivores or vole habitat management [36].

\section{Acknowledgements}

The work was supported by the Science Grant Agency VEGA project No. 2/0127/13 (0.4) and No. 2/0011/12 (0.4) and by the project "Application Centre for Protection of Humans, Animals and Plants against Parasites" (code ITMS: 26220220018), supported by the Research \& Development Operational Programme funded by the ERDF (0.2).

\section{Conflict of interest}

None declared.

Authors' contributions

Daniela Antolová and Martina Miterpáková provided investigation of red foxes and dogs for $E$. multilocularis presence using sedimentation and counting technique, ELISA and PCR methods; and human samples for alveolar echinococcosis by serological and molecular techniques. They were responsible for design and writing of the manuscript. Prof. Radoňák, prof. Szilágyiová, dr. Hudačková and dr. Žáček coordinated human sampling and data collection.

\section{References}

1. Eckert J, Deplazes P. Progress of drug treatment and new concepts for the management of the Echinococcus infection in definitive hosts. Arch Int Hidatid. 1997;32:202-5.

2. Romig T. Echinococcus multilocularis in Europe - state of art. Vet Res Commun. 2009;33(Suppl. 1):31-4. http://dx.doi.org/10.1007/S11259-009-9244-1

3. Vervaeke M, Giessen J, Brochier B, Losson B, Jordaens $\mathrm{K}$, Verhagen, $\mathrm{R}$ et al. Spatial spreading of Echinococcus multilocularis in red foxes (Vulpes vulpes) across nation borders in Western Europe. Prev Vet Med. 2006;76(3-4):137-50. http://dx.doi.org/10.1016/j.prevetmed.2006.04.014

4. Osterman Lind $E$, Juremalm $M$, Christensson D, Widgren S, Hallgren G, Ågren E O, et al. First detection of Echinococcus multilocularis in Sweden, February to March 2011. Euro Surveill. 2011;16(14):pll=19836.

5. Wahlström H, Lindberg A, Lindh J, Wallensten A, Lindqvist R, Plym-Forshell L, et al. Investigations and actions taken during 2011 due to the first finding of Echinococcus multilocularis in Sweden. Euro Surveill. 2012;17(28):pii=20215.

6. Enemark H L, Al-Sabi M N, Knapp J, Staahl M, Chriel $M$. Detection of a high-endemic focus of Echinococcus multilocularis in red foxes in southern Denmark, January 2013. Euro Surveill. 2013;18(10):pii=20420.

7. Commission Delegated regulation (EU) No 1152/2011 of 14 July 2011 supplementing Regulation (EC) No 998/2003 of the European Parliament and of the Council as regards preventive health measures for the control of Echinococcus multilocularis infection in dogs. Official J Eur Union. 2011; L 296/6-L 296/12. Available from: http://eur-lex.europa.eu/LexUriServ/ LexUriServ.do?uri=0J:L:2011:296:0006:0012:EN:PDF

8. Dubinský P, Svobodová V, Turčeková L', Literák I, Martínek $\mathrm{K}$, Reiterová K, et al. Echinococcus multilocularis in Slovak Republic: The first record in red foxes (Vulpes vulpes). Helminthologia. 1999;36(2):105-10.

9. Miterpáková M, Dubinský P. Fox tapeworm (Echinococcus multilocularis) in Slovakia - summarizing the long-term monitoring. Helminthologia. 2011;48(3):155-61. http://dx.doi.org/10.2478/s11687-011-0023-5 
10. Raoul F, Deplazes P, Nonaka N, Piarroux R, Vuitton DA, Giraudoux P. Assessment of the epidemiological status of Echinococcus multilocularis in foxes in france using ELISA coprotests on fox faeces collected in the field. Int J Parasitol. 2001;31(14):1579-88. http://dx.doi.org/10.1016/So020-7519(01)00280-6

11. Štatistické ročenky Slovenskej republiky. [Statistical Yearbook of the Slovak Republic]. Bratislava: Statistický úrad Slovenskej republiky [Statistical Office of the Slovak Republic]. [Accessed: 11 Apr 2013]. Slovak. Available from: portal.statistics.sk/ showdoc.do?docid=15949

12. Dinkel A, Nickisch-Rosenegk M, Bilger B, Merli M, Lucius $\mathrm{R}$, Romig T. Detection of Echinococcus multilocularis in the definitive host: coprodiagnosis by PCR as an alternative to necropsy. J Clin Microbiol. 1998;36(7):1871-6.

13. Kinčeková J, Hrčková G, Auer H., Szilágyová M, Hudačková J, Stanislayová $M$, et al. Clinical and serological study of human alveolar echinococcosis in Slovakia in relation to the outcome of chemotherapy. Helminthologia. 2006;43(4):213-9. http://dx.doi.org/10.2478/s11687-006-0040-y

14. Dražilová S, Kinčeková J, Beňa L', Zachar M, Švajdler $M$, Zavacký P, et al. Alveolar echinococcosis in patient after cadaveric kidney transplantation. Helminthologia. 2011;48(4):229-36. http://dx.doi.org/10.2478/s11687-011-0032-4

15. Schneider R, Gollackner B, Edel B, Schmid K, Wrba F, Tucek G, et al. Development of a new PCR protocol for the detection of species and genotypes (strains) of Echinococcus in formalinfixed, paraffin-embedded tissues. Int J Parasitol. 2008;38(89):1065-71.

http://dx.doi.org/10.1016/j.ijpara.2007.11.008

16. Kern P. Clinical features and treatment of alveolar echinococcosis. Curr Opin Infect Dis. 2010;23(5):505-12. http://dx.doi.org/10.1097/QCO.obo13e32833d7516

17. Zmena klímy Slovensko neobíde. [Climate change will not pass by Slovakia]. Bratislava: Priatelia zeme CEPA [Friends of the Earth Center for Environmental Public Advocacy (CEPA)]. [Accessed: 8 Aug 2014]. Slovak. Available from: www.priateliazeme.sk/cepa/en/informacie/ temy/989-zmena-klimy-slovensko-neobide

18. Kinčeková J, Auer H, Reiterová K, Dubinský P, Szilágyiová M, Lauko L, et al. The first case of autochthonous human alveolar echinococcosis in the Slovak Republic (Case report). Mitt Osterr Ges Tropenmed Parasitol. 2001;23:33-8.

19. Kinčeková J, Reiterová K, Dubinský P, Szilágyiová M, Johanes $R$, Gottas M. A second case of autochthonous alveolar echinococcosis in the Slovak Republic. Helminthologia. 2002;39(4):193-6.

20. Kinčeková J, Hrčková G, Bober J, Vrzgula A, Szabadošová $\mathrm{V}$, Bohuš $\mathrm{P}$, et al. A rare case of alveolar echinococcosis in 14-year-old child. Helminthologia. 2008;45(1):28-31. http://dx.doi.org/10.2478/s11687-008-0005-4

21. Tatranský národný park - základné informácie. [Tatra National Park - main information]. [Accessed: 21 Aug 2013]. Slovak. Available from: http://spravatanap.sk/web/index. php/2012-08-24-09-58-41/zakladne-informacie

22. Stehr-Green JK, Stehr-Green PA, Schantz PM, Wilson JF, Lanie A. Risk factors for infection with Echinococcus multilocularis in Alaska. Am J Trop Med Hyg. 1988;38(2):380-5.

23. Kern P, Ammon A, Kron M, Sinn G, Sander S, Petersen LR, et al. Risk factors for alveolar echinococcosis in humans. Emerg Inf Dis. 2004;10(12):2088-93.

24. Budke CM, Campos-Ponce M, Qian W, Torgerson PR. A canine purgation study and risk factors analysis for echinococcosis in high endemic region of Tibetian plateau. Vet Parasitol. 2005;127(1):43-9. http://dx.doi.org/10.1016/j.vetpar.2004.08.024

25. Ziadinov I, Mathis A, Trachsel D, Rysmukhambetova A, Abdyjaparov TA, Kuttubaev OT, et al. Canine echinococcosis in Kyrgyzstan: Using prevalence data adjusted for measurement error to develop transmission dynamic models. Int J Parasitol. 2008;38(10):1179-90. http://dx.doi.org/10.1016/j. ijpara.2008.01.009

26. Vuitton DA. The ambiguous role of immunity in echinococcosis: protection of the host or of the parasite? Acta Trop. 2003;85(2):119-32. http://dx.doi.org/10.1016/So001-706X(02)00230-9

27. Kern P, Bardonet K, Renner E, Auer H, Pawlowski Z, Ammann RW, et al. European Echinococcosis Registry: Human Alveolar Echinococcosis, Europe, 1982-2000. Emerg Infect Dis. 2003;9(3):343-9. http://dx.doi.org/10.3201/eido903.020341

28. Yang YR, Sun T, Li T, Zhang J, Teng J, Liu X, et al. Community surveys and risk factor analysis of human alveolar and cystic echinococcosis in Ningxia Hui Autonomous Region, China. B
Word Health Organ. 2006;84(9):714-21. http://dx.doi.org/10.2471/BLT.05.025718

29. Nahorski WL, Knap JP, Pawlowski ZS, Krawczyk M, Polanski J, Stefaniak J. Human alveolar echinococcosis in Poland: $1990-$ 2011. PLoS Neglect Trop Dis. 2013;7(1):e1986.

30. Malczewski A, Rocki B, Ramisz A, Eckert J. Echinococcus multilocularis (Cestoda), the Causative Agent of Alveolar Echinococcosis in Humans: First Record in Poland. J Parasitol. 1995;81(2):318-21. http://dx.doi.org/10.2307/3283945

31. Jorgensen P, an der Heiden M, Kern P, Schöneberg I, Krause G, Alpers K. Underreporting of Human Alveolar Echinococcosis, Germany. Emerg Infect Dis. 2008;14(6):935-7. http://dx.doi.org/10.3201/eid1406.071173

32. EFSA Panel on Animal Health and Welfare (AHAW). Scientific opinion of the European Union summary report on trends and sources of zoonoses, zoonotic agents and food-borne outbreaks - Terms of reference 2 to 7. EFSA J. 2013;11(1):3074. doi:10.2903/j.efsa.2013.3074.

33. Craig PS, Giraudoux P, Shi D, Bartholomot B, Barnish G, Delattre $P$, et al. An epidemiological and ecological study of human alveolar echinococcosis transmission in south Gansu, China. Acta Trop. 2000;77(2):167-77. http://dx.doi.org/10.1016/So001-706X(00)00134-0

34. Kreidl P, Allersberger F, Judmaie G, Auer H, Aspöck H, Hall AJ. Domestic pets as risk factor for alveolar hydatid disease in Austria. Am J Epidemiol. 1998;147(10):978-81. http://dx.doi.org/10.1093/oxfordjournals.aje.a009388

35. Hegglin D, Deplazes P. Control strategy for Echinococcus multilocularis. Emerg Infect Dis. 2008;14(10):1626-8. http://dx.doi.org/10.3201/eid1410.080522

36. Hegglin D, Deplazes P. Control of Echinococcus multilocularis: Strategies, feasibility and cost-benefit analyses. Int J Parasitol. 2013;43(5):327-37. http://dx.doi.org/10.1016/j.ijpara.2012.11.013

37. Statistical Yearbook of the Slovak Republic 2011. Bratislava: VEDA; 2011. p. 94-95. ISBN 978-80-224-1215-5 